\title{
O LEGADO MARXIANO E O PROBLEMA DA DEMOCRACIA ${ }^{1}$
}

\author{
Dick HOWARD 2 \\ Tradução do inglês: Álvaro L. HATTHER ${ }^{3}$ \\ Revisão Especializada: Isabel M. Loureiro4
}

\section{Dissonâncias cognitivas}

Os "eventos" do ano passado deveriam surpreender um esquerdista sério? Chamo essas mudanças maciças de "eventos", e coloco o termo entre aspas, numa alusão à forma como os franceses evitaram ajustar contas com sua própria e aparentemente inexplicável experiência em maio de 1968, quando um protesto estudantil iniciou uma cadeia de ações e reações que levou inesperadamente ao quase colapso de todo poder governamental - que, no entanto, foi seguida por eleições dando vitória esmagadora ao partido da ordem. Além do mais, uso o termo "partido da ordem" e não "da direita" ou "conservador" - muito menos "capitalista" - para recordar o fato de que, naquele mesmo ano de 1968, os dirigentes comunistas trouxeram a "ordem" de volta a Praga sobre as pesadas esteiras dos tanques do Pacto de Varsóvia. O inimigo polimórfico, de muitas cabeças, que aterroriza as noites do partido internacional da ordem, não é a esquerda, o socialismo - muito menos o "comunismo" -, mas sim a democracia. Esta não é uma observação tão banal quanto parece. Afinal de contas, quem se opõe à democracia? Ora, para ser sincero a respeito, muitos de nós da

1. A primeira versão foi publicada na Revista Praxis International, v. 10, n. 3/4, october 1990-january 1991, p. 193-204. Este artigo foi retrabalhado para um livro, Russia and America in the $21^{\text {st }}$ Century: Perspectives of Russian and American Philosophers, organizado por Bill Gay \& Tatjana Alekseeva, a ser publicada pela editora Rowman and Littlefield em 1993.

2. Prof. do Departamento de Filosofia da State University of New York at Stony Brook. Autor dos seguintes livros: From Marx to Kant, The Marxian Legacy, Defining the Political, The Politics of Critique. Escreve freqüentemente em: Esprit; Études, Libération, Neue Gesellschaft-Frankfurter Hefte.

3. Oficina de Tradução - IBILCE - Instituto de Biociências, Letras e Ciências Exatas - UNESP - 15054-000 - São José do Rio Preto - SP.

4. Faculdade de Filosofia e Ciências - UNESP - 17525-900 - Marília - SP. 
esquerda ocidental o fizeram - esquivando-nos de uma postura crítica ao dizer que aquilo a que nos opúnhamos era apenas a democracia "formal", que denunciávamos como ideológica. Mas o destino do "socialismo real" nos força a repensar nossos próprios valores e métodos políticos. E não podemos empreender essa reflexão como se fôssemos virgens em política. Temos um passado e vivemos em um presente; temos que atuar a partir das dissonâncias cognitivas que ambos produzem.

Retiro de meu próprio passado o modelo de Rosa Luxemburg, que usarei como fio condutor para entender o lugar da política democrática dentro do movimento da esquerda. Ela foi a crítica radical dos aspectos antidemocráticos da tomada do poder pelos bolcheviques em 1917, da mesma maneira que havia criticado a reforma do partido feita por Lenin quase quinze anos antes. E sua condição de revolucionária democrática confirmou-se em seu último artigo, escrito em meio às ruínas do levante Spartakista em janeiro de 1919. O título desse artigo, "A Ordem Reina em Berlim", não era meramente retórico, e seu tema permanece atual. O título, naturalmente, aludia à proclamação que se seguiu à derrota do levante polonês de 1831, mas Rosa Luxemburg tornou claras suas implicações contemporâneas: "Dessa forma correm os relatos dos guardiões da 'ordem' a cada meio século (...) E os 'vencedores' satisfeitos não percebem que uma 'ordem' que precisa ser mantida periodicamente por meio de chacinas sangrentas aproxima-se inabalavelmente de seu destino histórico, de sua destruição." Mas Rosa Luxemburg esperava que "a revolução" executasse a sentença da história. Assassinada no dia seguinte, ela tornou-se o primeiro ícone para aqueles que se recusaram a identificar o leninismo com o legado marxiano. ${ }^{5}$ Mas a relação prática e conceitual entre a revolução de Rosa Luxemburg e uma política radical, mas ainda democrática, permaneceu para ser explorada por seus herdeiros.

Buscando herdar o legado marxiano, muitos integrantes da esquerda ocidental do pós-guerra experimentaram a dissonância cognitiva em seus primeiros debates com seus pares socialmente críticos do Leste. Aquilo que pensávamos ser "a esquerda" era para eles o suporte das bases ideológicas de sua ordem estabelecida. Aquilo que consideravam "radical" era, para nós, o suporte dos princípios ideológicos de nossa própria ordem. Um exemplo bem conhecido ocorreu quando Rudi Dutschke levou uma delegação do SDS de Berlim para se encontrar com os estudantes rebeldes de Praga no começo de 1968. A esquerda ocidental estava ocupada descobrindo o marxismo; os tchecos estavam preocupados com as assim chamadas liberdades "formais", tais como o direito de manifestação pública ou de formar associações livres da tutela das autoridades. Apesar do fundamento óbvio para mal-entendidos, o diálogo aconteceu: inimigos de uma ordem que os depreciava como sendo "anarquistas", ambos os lados buscavam dar vida nova à democracia. Diferiam suas situações, e diferiam também suas soluções. Isso era de se esperar: a democracia não é uma forma universal, auto-idêntica e pura. Embora esse ethos democrático compartilhado tenha aparecido na prática durante o estonteante ano de 1968, ele não foi formulado teoricamente - pelo menos no Ocidente, onde o imperativo romântico e moral chamado "a revolução" obscureceu as reivindicações democráticas. 
Os dois lados poderiam ter tentado interpretar suas situações valendo-se de Rosa Luxemburg, outra assim chamada "anarquista". Ela havia descrito a "revolução" como "a única forma de 'guerra' (...) na qual a vitória final só pode ser preparada por uma série de 'derrotas'". Apesar dessa imagem sugestiva, apontando para o processo de aprendizado normativo necessário para que a política seja democrática, Luxemburg não identificava a "revolução" com a democracia que obcecava o partido da ordem. Ela ainda era uma marxista para quem o espectro "obsessivo" era sem dúvida o de Marx. A teoria de Marx servia-lhe como uma garantia da prática revolucionária. Ela recorre constantemente ao texto de Marx; por exemplo, sua crítica ao reformismo de Bernstein satisfaz-se em ter mostrado que "em sua essência, em suas bases, a prática oportunista é irreconciliável com o marxismo." De maneira semelhante, nas profundezas de uma guerra mundial, sua Brochura de Junius insistia que "a teoria marxista deu à classe operária de todo mundo uma bússola que lhe permitia encontrar 0 caminho no turbilhão dos acontecimentos quotidianos e fixar sua tática hora a hora em função do objetivo final, imutável. "6 Pode-se, é claro, apontar outros argumentos teóricos e práticos menos submissos e mais criativos. Mas a questão aqui é que não se pode resolver a dissonância cognitiva invocando-se "democracia", quer como um passe-partout que está acima de todas as outras posturas, quer como uma síntese que une, magicamente, política, sociedade e economia.

A "democracia" não elimina as diferenças reais, mesmo entre seus próprios partidários. Um outro exemplo de dissonância cognitiva, de uma outra parte do mundo, atesta a necessidade de aprender a política democrática. Um leitor ocidental contemporâneo do New York Times possivelmente não se surpreenderia com a seguinte passagem em um artigo recente sobre El Salvador: "Costumávamos marchar cantando, 'Socialismo, Socialismo '", disse o Rev. Rogelio Ponceele, um padre católico que viveu e trabalhou com a maior facção da guerrilha durante quase uma década, "Agora marchamos cantando, 'Democracia, Democracia!'”. Mas o que esse leitor diria sobre a continuação do mesmo artigo, onde se explica que, após uma década de luta, as tropas guerrilheiras não estão prontas a seguir seus líderes recém-convertidos? O Times explica isso como o resultado de um vácuo entre os líderes instruídos e os "camponeses com pouca instrução que a eles se uniram após sofrerem a repressão direitista."7 Rosa Luxemburg sugeriria uma leitura diferente. A "democracia" é mais do que um slogan usado para unir os excluídos contra o partido da ordem. Em sua polêmica contra o partido leninista, ela reconheceu que "o exército proletário é recrutado primeiro na própria luta", mas acrescentou a qualificação normativa de que "apenas na luta ele se torna consciente dos objetivos da luta." Essa insistência nos processos de aprendizado democrático é até mais explícita em sua defesa do programa da Liga Spartakus em 1919, ao concluir que "As massas precisam aprender a usar o poder usando o poder." ${ }^{8}$ Tais assertivas podem parecer justificar a crítica de "espontaneísmo" de Luxemburg. Mas elas colocam também a pergunta: o que se precisa aprender para ser um democrata herdeiro do legado marxiano? 
O partido da ordem acusou a nova Esquerda da década de 60 de ser "antiintelectual". A busca de uma resposta a essa crítica fez brotar um outro aspecto da dissonância cognitiva. Enquanto lia Anti-Intellectualism in American Life de Richard Hofstadter, fiquei surpreso com meu repetido alinhamento emocional com a rejeição dos antiintelectuais em relação a uma sociedade ressequida, formal e cada vez mais atomizada que conquistava de maneira incansável todos os aspectos da vida. Esta resposta instintiva foi reforçada pelo encontro inesperado com A Formação da Classe Operária Inglesa de E. P. Thompson e encontrou uma justificativa mais teórica em The Great Transformation de Polanyi. O quadro de uma "economia moral" protegendo-se da eficiência invasora do estado modernizador era interessante porque apontava para a fonte de um radicalismo nativo que promovia valores coletivos diante do individualismo egoísta da sociedade de mercado. Parecia também oferecer suporte à política "espontaneísta" de Rosa Luxemburg no panfleto Greve de Massas, cujo fundamento era o de que "as massas serão o coro ativo, e os líderes declamarão apenas algumas partes, sendo os intérpretes da vontade das massas." 9 Mas ao seguir o conselho de Luxemburg e reler Marx, percebi que essa imagem de uma economia moral é pré-moderna. O Manifesto Comunista apresenta um hino de louvor àquilo que Schumpeter veio a chamar de "destruição criativa " da modernização capitalista; com esse louvor surgiu uma crítica dos sonhos da vida comunal pré-capitalista que pode reproduzir apenas "o embrutecimento da vida rural." A crítica de Marx ao capitalismo não queria voltar a um tempo alegadamente melhor ou mais simples, anterior à disseminação da corrosiva influência da modernidade. Mas o conceito hegeliano de Aufhebung - preservação concomitante à ascensão a um nível mais alto - não explica como ele poderia louvar e criticar o que chama de "burguesia revolucionária". A mágica Aufhebungera apenas um acréscimo ao meu sentido de dissonância cognitiva.

\section{Além da democracia: totalitarismo?}

Por que continuar a recorrer a Marx, ou a Rosa Luxemburg, depois das experiências de 1989? A resposta depende de como definimos os novos desafios diante de nós. Eles não podem ser definidos simplesmente como a instituição de uma constituição que protege determinados direitos econômicos e sociais. Quais direitos? Quem decide? Os países chamados democráticos têm constituições diferentes e garantem de maneira mais ou menos estável os direitos políticos de seus cidadãos. É melhor definir esses regimes como liberais, deixando em aberto, por enquanto, a questão mais fundamental da natureza da democracia. ${ }^{10}$ Direitos que hoje parecem ser essenciais para as sociedades liberais geralmente são de safra recente - por exemplo, o direito das mulheres ao voto. E os mesmos direitos não estão presentes em todas as sociedades liberais - por exemplo, proteção à privacidade ou direito ao aborto. Esses direitos às vezes são violados: o sistema político nem sempre funciona 
como a constituição promete. A falta de um ou outro direito, ou até mesmo a violação ocasional de direitos ou de disposições constitucionais, não significa que esses regimes não sejam democráticos. Nem implica que se deva voltar à crítica marxista dos direitos como sendo "formal". Rosa Luxemburg entendeu melhor as implicações do legado marxiano quando, ao apresentar o programa da Liga Spartakus, insistiu que "Muito mais importante do que aquilo que está escrito em um programa é a forma pela qual isso é interpretado na ação." 11 Os direitos são garantidos apenas em uma luta histórica cuja questão central não é outra senão esses mesmos direitos. A abertura para essa forma de ação política é o que torna uma sociedade democrática. Além disso, há a implicação de que as sociedades democráticas são históricas e que seu futuro depende da forma como os direitos são "interpretados na ação".

Mas não se pode escapar de Marx tão facilmente. O fato de que os direitos liberais formais precisam de proteção aponta para a necessidade de dar-lhes uma base mais segura e substancial. Mas essa separação entre uma base material e os direitos que aquela supostamente garante tem tido, de maneira freqüente, conseqüências políticas infelizes. Ela sugere que os direitos podem ser suspensos "temporariamente" a fim de se construir a base que possibilitará a todos os cidadãos desfrutar desses mesmos direitos. Isso significa descer o primeiro degrau da escada escorregadia que leva, na melhor das hipóteses, ao despotismo esclarecido. Duas alternativas parecem possíveis hoje: o "socialismo democrático", como a Terceira Via tão procurada por tantos; ou o retorno ao processo de desenvolvimento autóctone pré-totalitário que é construído a partir da história peculiar de cada nação. Mas ambas essas opções assumem que o totalitarismo foi imposto sobre a sociedade de fora, por um fiat político externo. No primeiro caso, diz-se que essa imposição política teria sido necessária devido à incapacidade da burguesia nativa para assumir seu papel; no segundo caso, a política totalitária parece ter interferido em um desenvolvimento endógeno harmonioso. Os partidários das duas opções fariam bem em lembrar-se da advertência de Rosa Luxemburg à Liga Spartakus para que não imitassem "as revolucões burguesas nas quais bastou derrubar aquele poder oficial no centro e substituir uma meia dúzia de pessoas que detinham a autoridade." ${ }^{12}$ A implicação é a de que ambas as supostas alternativas partilham uma hipótese comum acerca da relação entre política e sociedade: a busca por uma Terceira Via transforma a política na variável independente; o recurso à história faz da sociedade a determinante primária. Como podem as duas posturas se unir e de maneira harmoniosa?

Rosa Luxemburg viu o problema e sua tentativa de solucioná-lo nos permitirá enxergar tanto a fraqueza do marxismo quanto a força de Marx. Luxemburg apontou reiteradamente para a necessidade de se navegar entre "o abandono do caráter de massa ou o abandono do objetivo final; a recaída no sectarismo ou no reformismo burguês; anarquismo ou oportunismo." 13 Ela pensava poder sintetizar esses "dois escolhos" na "greve de massas" onde "a luta econômica é aquela que conduz a luta política de um ponto nodal a outro; a luta política é aquela que periodicamente fertiliza o solo para a luta econômica. Aqui, causa e efeito trocam constantemente de lugar." 14 
Porém, essa síntese atraente ainda é produzida pelo acréscimo de mágoas particulares e protestos individuais. Seu resultado político aparece na alternativa de Luxemburg a Lênin. Seu partido "torna-se gradualmente o refúgio dos diferentes elementos insatisfeitos da sociedade, tornando-se o partido do povo oposto à pequena minoria da burguesia dominante." 15 Mas essa política não é nova: ainda se baseia no protesto imediato e não em um debate público e em uma avaliação crítica. Aqui Luxemburg continua marxista: ela está tratando a sociedade como sendo determinada por suas bases econômicas. Ainda assim, as idéias mais radicais que a tornam parte do legado marxiano basearam-se na suposição de uma sociedade democrática.

O ponto de partida para a elaboração de conceitos sobre a sociedade democrática pode ser encontrado no jovem Marx. Ele aprendera com Hegel que o nascimento de uma "sociedade civil", que não pode ser redutível à esfera privada nem é capaz de ser absorvida pelo estado político, é a marca da modernidade. Embora suas últimas obras reduzissem sua "anatomia" a meras relações econômicas, Marx freqüentemente demonstrou ter consciência de sua complexidade. As duas abordagens podem ser encontradas no Manifesto Comunista. A descrição de Marx daquilo que chama de empreendimento revolucionário da burguesia não pode ser reduzida nem a relações econômicas nem a imperativos políticos. "Todas as relações fixas, cristalizadas, com seu cortejo de preconceitos e idéias antigas e veneradas são suprimidas", escreve Marx, "todas as novas relações se tornam antiquadas, antes mesmo de se consolidar. Tudo que é sólido desmancha no ar, tudo que é sagrado é profanado, e por fim o homem é obrigado a encarar com serenidade suas verdadeiras condições de vida e suas relações com a espécie." Novas necessidades podem surgir agora; novas formas de comunicação produzem uma nova civilização; as cidades "resgatam" o campesinato do "embrutecimento da vida rural". Essas são as bases para se ler Marx como o primeiro modernista. ${ }^{16}$

O leitor contemporâneo dessas linhas impressiona-se com outro aspecto das considerações de Marx. Além da costumeira retórica, sua análise poderia ter sido escrita por Tocqueville. ${ }^{17}$ Mas então pode-se perguntar por que Marx reduz a revolução social que descreveu ao simples resultado de uma contradição entre as relações feudais de propriedade e as forças produtivas que devem ser "despedaçadas". A razão se torna clara quando Marx prontamente generaliza aquele modelo economicista para retratar o advento da revolução proletária, segundo as linhas sugeridas pelo "partido do povo" de Luxemburg. Isso leva à consecução de dois objetivos: fornece uma base material para a liberdade e os direitos que Marx deseja defender; e seu embasamento numa filosofia da história como luta de classes que será, por fim, superada implica que a transformação histórica não mais será uma ameaça para a futura sociedade comunista. Mas o preço pago por essa certeza teórica é grande demais: a suposta garantia material torna desnecessário o debate político democrático, enquanto que a garantia filosófica de unidade bloqueia a visão de um futuro aberto sobre o qual a sociedade necessitaria discutir. Nesse quadro, não há lugar para o crítico nem para o espaço público no qual o julgamento pode se formar. 
Um quadro diferente emerge quando a sociedade moderna de Marx é lida pelos olhos de Tocqueville. A "burguesia revolucionária" é vista como produtora de uma sociedade democrática. Sua eliminação das certezas "sólidas" e a profanação do "sagrado" assinalam o fim de uma sociedade na qual cada um tem seu lugar e seu papel; o indivíduo moderno nasce e deve enfrentar, com "serenidade", o problema de quem ele é e com quem ele irá se relacionar. Marx não fala sobre direitos nesse contexto porque suas primeiras críticas a Hegel ensinaram-lhe que tais direitos eram apenas formais. Mas seu contraste da sociedade feudal e burguesa deveria ter conduzido a uma conclusão diferente. Os "direitos" feudais são atributivos; são impostos de fora sobre a pessoa, por Deus e pela natureza "sólida" das coisas. Por outro lado, o indivíduo moderno vive em um mundo sem fundamentos; se esse indivíduo tem direitos, os fundamentos desses direitos só podem ser políticos. Eles são conquistados e garantidos apenas na luta. Isso sugere que o revolucionamento constante das relações sociais no capitalismo é um desafio renovado aos recém-conquistados direitos do indivíduo. Implica, também, que o capitalismo não é apenas um modo de produção; a história das lutas de classes precisa ser reinterpretada como a história da política de direitos; e, contrariamente à história economicista, essa história dos direitos nunca terminará em uma grande unificação. Em uma sociedade democrática cujo fundamento é o indivíduo moderno, não pode haver o recurso a uma base de direitos material ou transcendente; a história permanece aberta e a política continua sendo necessária. A democracia não é formal, mas a experiência vivida de uma luta por direitos não pode terminar nunca.

Essa interpretação da democracia sugere um novo modelo para o entendimento da emergência do totalitarismo. A sociedade moderna habitada pelo indivíduo radicalmente livre é inquietante, homens e mulheres são átomos, juntos e solitários naquele espaço infinito tão temido por Pascal. Embora, é claro, nunca admitissem, eles sabiam que o Manifesto estava correto: os direitos que têm hoje, assim como o espaço que ocupam, podem ser "suprimidos" ou "tornarem-se antiquados, antes mesmo de se consolidar." É essa experiência vivida que faz com que os direitos pareçam meramente formais, e a democracia um luxo. A demanda por uma democracia "real" e/ou por uma verdadeira comunidade cresce; a divisão social é intolerável, uma ameaça à própria existência do indivíduo. Surge a busca por raízes, por algo "sólido" e até mesmo "sagrado"; um movimento emerge, talvez fascista, talvez comunista. ${ }^{18}$ Mas esses movimentos saltam para um momento qualitativamente novo na história política apenas de forma aparente. O totalitarismo não está além da democracia: ele é imanente à lógica da democracia - da mesma forma que a "greve de massas" que navega magicamente entre os "dois escolhos" de Rosa Luxemburg. Tanto a democracia quanto o totalitarismo emergem da experiência de divisão social em uma sociedade de indivíduos alienados; a democracia busca preservar essa divisão criando um espaço público dentro do qual uma política de direitos (incluindo os direitos econômicos) pode ocorrer, ao passo que o totalitarismo quer superar a divisão por meio de uma nova unidade. Assim, o totalitarismo parece ser a solução lógica para 
as tensões da sociedade democrática. Nesse sentido, o totalitarismo é uma antipolítica. ${ }^{19}$

A afirmação de que o totalitarismo é imanente à lógica da democracia implica que essa democracia não é um estado de coisas; ela não é o ideal liberal estático da proteção formal dos direitos básicos. A sociedade descrita por Marx e reinterpretada por Tocqueville não é estável. Seria preferível falar em uma dinâmica da democratização, para nos referirmos ao processo cujas origens residem na modernização que suprime as certezas da antiga ordem. ${ }^{20}$ Mas o totalitarismo não pode impor unidade a uma sociedade moderna; sua "política" é aplicada verticalmente, de cima para baixo, buscando constantemente atomizar quaisquer tentativas de formas horizontais de associação que possam criar uma nova esfera pública. Mas exatamente pelo fato de ser imanente às sociedades democráticas modernas, o projeto totalitário está condenado ao fracasso. Não é de surpreender a rapidez com que caiu. Sua própria lógica volta-se contra ele. Se fosse realizado, sua própria base - a sociedade de indivíduos que têm que buscar constantemente suas próprias raízes e seus próprios direitos seria obliterada. Não há dúvida de que políticas autocontraditórias podem ser impostas à força; mas quando essa pressão externa é retirada, tais políticas entram em colapso, caindo no nada.

O que resta, quando se evita a alternativa totalitária, ainda precisa ser analisado. Dois séculos atrás, James Madison enfrentou um problema semelhante em sua tentativa de justificar a nova Constituição Americana. Em seu famoso capítulo X de O Federalista, ele afirmava que, para curar a forma de divisão social denominada "facção", podia-se destruir "a liberdade essencial à sua existência", ou podia-se dar "a todos os cidadãos as mesmas opiniões, as mesmas paixões e os mesmos interesses." O primeiro remédio, continua ele, seria "pior do que a doença", enquanto o segundo não só é "impraticável", mas também uma negação da "primeira finalidade do governo" ${ }^{21}$ A solução de Madison era multiplicar o número de facções, de forma que cada uma possa fiscalizar a ameaça da outra, preservando uma sociedade democrática dentro do modelo de uma república representativa. Devemos prestar atenção nisso: a democracia de Madison não era baseada na soberania democrática. Seu discernimento dizia-lhe que é necessário um estado republicano representativo a fim de preservar uma sociedade democrática. Madison certamente não se teria surpreendido com o colapso rápido e radical dos estados totalitários após 1989.

\section{O Estado moderno/modernizador}

A rejeição de Madison à soberania democrática tem outra implicação. Se a nova sociedade democrática fosse o resultado da ação da burguesia "revolucionária", o economismo marxista ainda poderia fazer sentido. Mas Tocqueville demonstrou que a mesma sociedade democrática emergente era o produto de um estado modernizador, 
que buscava garantir sua soberania absoluta. ${ }^{22}$ Claude Lefort argumenta que a negligência de Marx em relação a esse estado modernizador explica sua incapacidade de entender a autonomia da sociedade democrática. ${ }^{23}$ O Manifesto Comunista passa do feudalismo ao capitalismo sem considerar o estado absolutista, cuja noção de soberania permanece conosco até hoje. Assim, quando Marx analisa a Declaração dos Direitos do Homem, da Revolução Francesa, ele não consegue entender a importância desses direitos, que lhe parecem ser apenas formais. Segudo Marx, a liberdade de fazer tudo aquilo que não prejudique os outros apenas protege a mônada egoísta ao invés de libertar o indivíduo da sociedade hierárquica e de abrir a possibilidade de formação de novos laços sociais. O mesmo se aplica à distinção entre as esferas pública e privada, o que não é apenas uma formalidade, como pensa Marx, mas sim a garantia de um direito que torna o indivíduo livre. Também não são formais a liberdade de opinião e de expressão; elas criam uma esfera pública que assegura que o conhecimento não vai se manter como monopólio daqueles que estão no poder. De forma semelhante, o direito à segurança não pode ser reduzido à proteção da propriedade capitalista; ele também protege o cidadão das ações arbitrárias e conseqüentemente afirma a autonomia que permite ao indivíduo ser um cidadão com consciência crítica. O parcialismo de Marx faz com que ele até mesmo ignore a implicação histórica da presunção da inocência, que para Lefort é "uma aquisição irreversível do pensamento político."24

Entretanto, ao se analisar a relação entre o estado absolutista e a burguesia "revolucionária" de Marx nas diversas histórias nacionais, um ponto permanece comum. A centralização e o novo conceito de soberania destruíram o cosmo hierárquico e ordeiro herdado da sociedade tradicional. Surgiu uma nova matriz: o indivíduo e uma política de direitos tornaram-se possíveis. A sociedade individualista emergente pode aliar-se ao monarca contra a aristocracia; ou pode unir-se à aristocracia para atacar o monarca. Mais importante do que esses conhecidos campos-de-força econômicos é a nova configuração que opõe a sociedade ao Estado. Esta polarização não deveria ser identificada com uma história marxista da luta de classes, cujo objetivo é atingir uma previsível síntese, ou pelo menos a eliminação de um dos pólos em benefício do outro. Essa visão é mais complexa do que a de Marx, porque a própria sociedade é uma diversidade democrática de indivíduos cuja unidade e divisão são estruturadas pelo sistema de direitos assegurados pelo Estado. ${ }^{25}$ Pelo fato de esses direitos servirem para preservar tanto a diversidade quanto a unidade, são objeto de uma luta que nunca poderá ter fim. O estado afirma sua soberania na proteção desses direitos individuais e também na garantia de um espaço no qual a sociedade possa buscar a afirmação de novos direitos. Essa era a definição norte-americana, de Madison, de "primeira finalidade do governo". Mas tem ascendência européia no estado absoluto, cujo primeiro teórico, Jean Bodin, intitulou seu tratado de Os Seis Livros da República!

Esse modelo permite uma reinterpretação da história que produziu tanto o capitalismo quanto o totalitarismo. O estado modernizador - e não a "burguesia 
revolucionária" de Marx - aplica sua nova concepção de soberania. O resultado cria as condições para a democratização da sociedade. Produz uma sociedade marcada pelo individualismo, pela diferença e pela divisão. Mas essa sociedade também está à procura de comunidade, identidade e unidade. O estado nacional, de forma apenas aparente e por um breve momento no século XIX, fornece essa ligação. Sua posição como fiador dos direitos exige que se posicione do lado de fora da sociedade. Se reivindicar ser idêntico à sociedade, cedo ou tarde ele parece ter inevitavelmente assumido um lado nas divisões inerentes à sociedade democrática e deve pagar o preço por isso na moeda da perda de legitimidade. ${ }^{26}$ Pode evitar essa perda apenas por meio de uma tentativa de encarnar alguma necessidade ou valor imanente à sociedade. Entretanto, essa medida o coloca no caminho em direção ao totalitarismo. Sua reivindicação de identidade com a sociedade nega a diversidade típica da sociedade democrática recorrendo a uma unidade putativa, provida por um Volk místico ou por uma lógica do caminho necessário na história.

Mas o totalitarismo não é o único caminho pelo qual a sociedade democrática pode buscar unidade. O capitalismo faz a mesma reivindicação no que diz respeito à imanência social. O mercado neutro substitui o estado neutro; os interesses econômicos são substituídos pelos direitos políticos. Da mesma forma que o totalitarismo, o capitalismo é uma antipolítica. Ele nega sua própria natureza política. O inimigo do capitalismo não é o proletariado, mas a democracia, cuja política baseia-se nos Direitos do Homem. O capitalismo, assim como o totalitarismo, procura eliminar a divisão social; a fim de controlar os efeitos de sua constante revolução das relações sociais, ele tem que basicamente reduzi-las a uma forma quantitativa idêntica. $\mathrm{O}$ resultado disso é o individualismo atomizado, que é incapaz de formular quaisquer normas políticas legítimas porque seu único padrão de julgamento é a lógica quantitativa de seu próprio individualismo abstrato. A superação capitalista da divisão social também é antipolítica nesse segundo sentido. Ela é incapaz de elaborar qualquer projeto que forneça à sociedade uma imagem positiva de si própria. Conseqüentemente, não possui normas que possa opor às enormes desigualdades que surgem exatamente na base da lógica da igualdade abstrata do mercado.

As lutas que os marxistas chamam de "anticapitalistas" podem ser interpretadas dentro desse modelo de democracia. Não é necessário negar o papel do interesse; a análise de Madison sobre as facções reconhecia que "da proteção de capacidades diferentes e desiguais de aquisição de propriedade resulta imediatamente a desigualdade na extensão e natureza da propriedade," e que "a origem mais comum e durável das facções tem sido a distribuição diversa e desigual da propriedade." De fato, para Madison, o desenvolvimento dos interesses parecia ser a marca das "nações civilizadas" ${ }^{27}$ Mas o interesse e mesmo a posse de quantidades desiguais de propriedade não são idênticos ao capitalismo. Mais exatamente, o desafio colocado pelas lutas populares é "anticapitalista" no sentido específico sugerido aqui: elas põem em discussão a assertiva de que a economia capitalista proporciona essa unidade imanente, destruída pelo nascimento da sociedade democrática, moderna e indivi- 
dualista. Esses movimentos afirmam o caráter aberto e democrático de uma sociedade na qual a luta política é legítima. São afirmações de direitos ou, nas palavras de Lefort, do direito de ter direitos. Não se conclui a partir daí que todos os movimentos populares devam ser apoiados; essa decisão é o objetivo do debate público e dos julgamentos críticos. No entanto, pode-se concluir que devem ser rejeitados quaisquer movimentos que se recusem a fazer parte desse processo democrático, alegando que seus valores ou objetivos representam a verdade ou a unidade imanentes da sociedade. ${ }^{28}$

\section{O partido da desordem}

Esta discussão teve seu ponto de partida no conflito entre o "partido da ordem" e os membros da Nova Esquerda a quem chamei de democratas. Usei Rosa Luxemburg, a mais rigorosa - e, portanto, a mais contraditória - dos marxistas como pano de fundo para uma tentativa de apresentar um amplo modelo no qual o legado marxiano - e o problema das sociedades pós-totalitárias - pudesse ser interpretado. A hipótese sugerida por Claude Lefort, de que tanto o capitalismo quanto o totalitarismo são tentativas de estabelecer um fechamento imanente ou legitimação para uma sociedade dividida que não pode recorrer a normas transcendentes, permite uma reinterpretação da história das lutas populares nos últimos dois séculos. Por um lado, ela sugere que esses movimentos podem - mas não precisam - mover-se em uma direção que sustenta a solução totalitária. Isso explicaria por que tantos - incluindo os camponeses salvadorenhos e os jovens alemães de esquerda em visita a Praga que mencionei - podem se perceber aliados a escolhas políticas cujos resultados básicos eles mesmos viriam a deplorar. A história dos companheiros de viagem, que Lefort deprecia como sendo o partido dos bien-pensants, pode ser entendida a partir dessa perspectiva. ${ }^{29}$ Mas para além dessa solução conceitual para meu enfrentamento com a "dissonância cognitiva" na onda dos "eventos" de 1989, existe ainda o problema emocional suscitado pela tentação "antiintelectual" de uma "economia moral". Para lidar com ela, introduzirei, por fim, uma outra dissonância cognitiva: a experiência da Alemanha Oriental.

Por que aqueles grupos de oposição, cuja postura corajosa expôs a nudez das alegações totalitárias, foram incapazes de exercer um papel político depois do colapso do regime? Parece que, dada a alegação totalitária, apenas uma postura moral poderia desafiar sua legitimidade, da mesma forma que foi necessária uma certeza moral para apoiar a recusa individual em aceitar o regime total. Para ser mais do que uma recusa individual, a oposição teria que assumir estar falando por uma coletividade que fora suprimida e que emergiria depois que a opressão se dissipasse. ${ }^{30}$ Mas, pensavam alguns, isso seria a substituição de um absoluto por outro, de uma totalidade por outra; a oposição seria a "porta-voz" de uma minoria ainda silenciosa. E, então, quando o regime caiu, e a sociedade se viu sozinha, a oposição não conseguiu aceitar a 
legitimidade de uma política cujo fundamento é a pluralidade do interesse faccional. A maior força da oposição torna-se agora a origem de sua fraqueza. Ela não conseguia entender o materialismo desencadeado no curso da Queda. Mas com que bases a oposição poderia criticar tal comportamento regido pelos interesses pessoais? Não teria ela que recorrer, implícita ou explicitamente, a um conceito de unidade, à idéia de uma sociedade que estaria finalmente, por meio do conhecimento e comportamento adequados, reconciliada consigo mesma para além das divisões? Isso então a tornaria, apesar dela mesma, uma parte do partido da ordem? O seu objetivo implícito seria não só a substituição da velha ordem, mas a criação de uma nova ordem moral?

Embora seu recurso ao Acordo de Helsinque lhe propiciasse um importante componente democrático, a orientação moral da oposição no Leste foi fortalecida pela forma de interpretação dos princípios de Helsinque. Os direitos que estes ratificavam foram concebidos dentro do modelo daquilo que foi definido acima como sendo liberalismo; não eram os direitos que definem o espaço público de uma sociedade democrática, na qual a política é a luta por direitos que têm como única garantia o processo político pelo qual foram conquistados e reafirmados. Tais direitos estáveis podem tornar-se a matéria-prima do moralismo. Eles contribuem para a impressão de que a representação política e a batalha entre os partidos concorrentes são um degrau em direção ao caminho da perdição, na medida em que destroem a harmonia e a ordem da sociedade que está buscando afirmar-se contra o estado. Dessa forma, o dualismo estático que caracterizou a busca pela Terceira Via, ou o retorno à história nacional autóctone, substitui a dinâmica da política democrática. O ressurgimento dessa estrutura sugere que, mais uma vez, o desafio a ser enfrentado é a manutenção da dinâmica da democracia contra a tentação de pôr um fim à sua interminável e dolorosa falta de certezas. É claro que as novas sociedades do Leste - assim como as do Ocidente - não são tão democráticas quanto gostaríamos que fossem; mas são mais democráticas do que gostariam muitos daqueles que foram forçados a ajudar em sua criação. E, o que é mais importante, elas podem tornar-se mais democráticas, se esse for realmente o objetivo que almejamos.

O diálogo renovado entre o Leste e o Ocidente permite aos dois lados redescobrir aquilo que tornou "de esquerda" suas políticas. Da mesma forma que em 1968, os radicais do Leste e do Ocidente podem encontrar uma base comum somente em torno do desafio de realizar a democracia. Também como em 1968, eles são o "partido da desordem". Mas agora a crítica do totalitarismo feita pelo Leste e a crítica do capitalismo feita pelo Ocidente podem atuar em série: o Ocidente pode aprender com o Leste que sua democracia não é apenas um sistema estático de direitos liberais, enquanto que o Leste pode aprender com o Ocidente que o capitalismo é apenas uma outra forma de reduzir à neutralidade quantitativa do mercado as diferenças qualitativas produzidas dentro das sociedades democráticas. Os dois sistemas são inimigos da democracia. Por sua vez, a democracia possui agora uma base histórica e teórica que evita a acusação de formalismo e de abstração que contribuíram para o atrativo do Marxismo. Agora que a história não nos fornece mais o vetor da verdade, e agora 
que os direitos estão sendo constantemente desafiados, não existe nenhuma "postura politicamente correta ": existe apenas a política. De maneira paradoxal, no Ocidente, isso tem conduzido a um endurecimento de posições; a ideologia parece contar mais do que a crítica; aqui deve-se afirmar a própria identidade, e validá-la estando "do lado correto". No Leste, a mesma lógica paradoxal assume uma forma diferente: busca-se colocar uma nova ciência no lugar da ideologia, e acaba-se transformando em fetiche a noção de "necessidade". O velho voluntarismo é substituído por um novo positivismo que igualmente não possui base política.

O "partido da desordem" defende a prioridade do político, no Ocidente e no Leste. Sua percepção básica é a de que a política define aquilo que conta como necessário, aquilo que uma sociedade empreende ou modifica, bem como aquilo que ela deixa para seguir seu próprio curso natural. Ele aceita a distinção de André Gorz entre uma "lógica do capital" e uma "lógica do capitalismo" e tenta fazer com que a primeira não seja imposta involuntariamente sobre a segunda ${ }^{31}$. É claro que o "partido da desordem" tem seus programas. Ele vai às ruas, ao palanque, ao espaço público porque tem objetivos concretos e argumentos para defendê-los. Sabe que a sociedade precisa ser governada, que decisões têm que ser tomadas, que recursos têm que ser alocados. Mas sabe também que essas são escolhas políticas, não respostasà "charada da história" de Marx ou às necessidades impostas pela lógica abstrata do mercado. Mas a política só é defensável por meio de discussões, programas e práticas. Devido à sua insistência no fórum público, onde as opiniões se chocam e o julgamento emerge a partir do debate crítico, o partido da desordem não rejeita as dissonâncias cognitivas, mas amadurece a partir delas. Talvez seja por isso que, no final das contas, ele permaneça, criticamente, dentro do legado marxiano.

\section{Notas}

5. O artigo de Luxemburg está traduzido em Selected Political Writings of Rosa Luxemburg, editado por Dick Howard (Nova York: Monthly Review Press, 1971). Meu entendimento da noção de "legado marxiano", que prefiro ao conceito "Marxismo Ocidental", de Merleau-Ponty, freqüentemente usado, está delineado em meu próprio livro com aquele título, onde o primeiro capítulo apresenta o caráter contraditório daquele legado por meio de um reexame da vida e do pensamento de Luxemburg de forma mais crítica do que aquele que apresentei na Introdução a seus Escritos. Cf. The Marxian Legacy, 2. ed., Mineapolis: University of Minnesota Press Londres: Macmillan, 1987. Vou usar Luxemburg como uma espécie de baliza para as reflexões da primeira parte deste ensaio porque - de maneira oposta a Marx, para quem uma teoria política autônoma é impossível no capitalismo e desnecessária no socialismo - ela defende aquele aspecto da tradição marxiana que ao menos percebia a necessidade de uma teoria política adequada, ainda que suas suposições teóricas tornassem impossivel a sua elaboração.

6. Citações de op. cit., p. 120 e 325. 
7. Lindsey Gruson, "Among Salvadora Rebels, A Split Over Rights Accord ", The New York Times, 11 de agosto de 1990, p. 2.

8. A primeira citação foi retirada de Greve de massas, partido e sindicatos, ibid., p. 270; a segunda citação é de Nosso Programa e a Situação Política, ibid., p. 406. As citações poderiam se multiplicar, com contra-exemplos sendo apresentados, como fiz em The Marxian Legacy. No presente contexto, o ponto a ser salientado, e ao qual voltarei, é o de que esse processo tem dupla imılicação: a raiva particular torna-se uma reivindicação pública que, por estar agora representada no fórum público, deve respeitar sua própria diferença em relação a outras reivindicações também presentes nesse mesmo fórum. Isso possibilitará ao novo poder democrático evitar a tentação de tornar-se simplesmente uma outra variante do velho "partido da ordem".

9. Greve de massas, partido e sindicatos, in: op. cit., p. 270.

10. Essa distinção é salientada em Jean Cohen em "Discourse Ethics and Civil Society", Philosophy and Social criticism, v. 14, n. 3-4, p. 315-37, 1988.

11. Nosso Programa e a situação política, ibid., p. 380.

12. Nosso Programa e a situação política, ibid., p. 380.

13. "Militia and Militarism", ibid., p. 142; e novamente em "Questões de organização da social-democracia russa", ibid., p. 304.

14. Greve de massas, partido e sindicatos, op. cit., p. 241.

15. "Questões de organização da social-democracia russa", ibid., p. 303.

16. Tentei mostrar essa idéia em "The Politics of Modernism: From Marx to Kant ", reimpresso em The Politics of Critique e em outros ensaios. Cf. tbm. Marshall Berman, All that is Solid Melts in the Air, reimpresso em Irving Howe, ed., 25 Years of Dissent, Nova York: Methue, 1979.

17. A análise de Tocqueville da democracia como uma estrutura social e sua tentativa de formular uma teoria política que permitisse desdobramentos férteis, evitando, ao mesmo tempo, suas possibilidades negativas admitem uma releitura hoje - como demonstram pensadores franceses como Claude Lefort, François Furet e Marcel Gauchet. No presente contexto, devemos nos lembrar de que a tarefa de Tocqueville, no curso da Revolução de 1830 em A Democracia na América, e na esteira dos acontecimentos da Revolução de 1848 e do coup de Bonaparte em 1851 em O Antigo Regime e a Revolução, era entender de que maneira as vitórias sociais alcançadas em 1789 podiam ser preservadas por meios políticos. Aqueles que se deparam com os resultados das revoluções democráticas de 1989 podem lê-lo com proveito.

18. A questão do nacionalismo também poderia ser inserida nesse modelo geral. No entanto, teríamos que distinguir entre a forma de nacionalismo que surgiu no século XIX, como sendo uma resposta aos desafios sociais apresentados pela burguesia "revolucionária", e os nacionalismos do século XX que surgem para enfrentar a erosão desencadeada pelos processos econômicos do capitalismo. O ressurgimento do nacionalismo nas sociedades pós-totalitárias representaria uma terceira variante dentro desse modelo.

19. O totalitarismo não é o tipo de "antipolítica" que os oposicionistas do Leste Europeu, tais como G. Konrad, procuraram teorizar como sendo uma nova postura política dentro e contra o totalitarismo. Essa antipolítica é um exemplo daquilo que considero aqui uma 
política democrática de direitos. De fato, o totalitarismo não pode impor unidade à sociedade; suas ações "políticas" atomizam verticalmente quaisquer tentativas de grupos dentro de uma sociedade civil que tentam se constituir horizontalmente. Como veremos em breve, o capitalismo produz um efeito semelhante por meio da operação quantitativa de sua lógica de mercado. Isso explica a reivindicação dos radicais tchecos em seu enfrentamento com o SDS alemão em 1968 pelo direito de livre reunião, assim como a capacidade dos alemães de entender intuitiva, quando não conceitualmente, os tchecos. Entretanto, o problema hoje é que esse tipo de política oposicionista alcançou o poder e tem que identificar e enfrentar necessidades sociais e econômicas difíceis de serem integradas à política de direitos. Voltarei a esse problema em minhas conclusões.

20. Para evitar qualquer mal-entendido histórico, devo salientar que o totalitarismo tende a apresentar-se como uma possibilidade em situações nas quais o processo democrático está começando a se instaurar. Poder-se-ia citar exemplos como a Rússia, a Alemanha de Weimar, a Espanha republicana, talvez até a China de Sun Yatsen. Por outro lado, mesmo dentro de sociedades onde a democracia se tornou uma forma instruída de comportamento político, os movimentos radicais que se autodenominam "de esquerda" têm constantemente enfrentado o fato de se acharem denunciando liberdades "formais", manipulações ideológicas e o cotidiano da busca da política eleitoral por um "centro" mítico. Democracias estabelecidas, como a França e a Itália, ou mesmo os Estados Unidos durante a Depressão, podem dar à luz movimentos cuja tendência seja totalitária. Pode-se tentar distinguir, por exemplo, entre "direitos sociais" e "cidadania social" e sugerir que a segunda não é suficiente. $O$ terreno aqui é escorregadio porque a sociedade democrática não é um estado de coisas, mas um desafio constantemente repetido que nunca pode ser abandonado em função da descoberta ou produção de fundamentos básicos. Deus, de fato, está morto.

21. Alexander Hamilton, James Madison e John Jay, The Federalist, Jacob E. Cooke, ed., Middletow, Connecticut: Wesleyan University Press, 1961, p. 61. Sobre a singularidade da experiência norte-americana, e sua relevância para os debates atuais, cf. Dick Howard, The Birth of American Political Thought, David Curtis, trad., Londres: Macmillan e Minneapolis: University of Minnesota Press, 1990.

22. A demonstração de Tocqueville sobre essa questão pode ser encontrada, é claro, em $O$ Antigo Regime e a Revolução e não em A Democracia na América. A relação dos conceitos de democracia nessas duas obras mereceria um estudo à parte. No presente contexto, a consulta à obra de Claude Lefort deverá bastar.

23. Devo reconhecer meu débito para com Lefort pelo esboço anterior da relação entre sociedade democrática e totalitarismo. Para detalhes e referências, cf. The Marxian Legacy, op.cit., Capítulo 7, e o Posfácio à segunda edição.

24. Claude Lefort, L'invention démocratique. Les limites de la domination totalitaire, Paris: Fayard, 1981, p. 61.

25. Enfrentamos essa polaridade entre sociedade e Estado na busca política de uma Terceira Via, ou a tentativa de voltar a uma forma de desenvolvimento histórico autóctone. É aí que encontramos suas raizes teóricas. É importante salientar o aparente paradoxo segundo o qual o nascimento do indivíduo soberano e autônomo coincide com, e é logicamente correlato à emergência do estado nacional soberano. Se pretendermos buscar formas "pós-modernas" do estado nacional, novos tipos de confederações e assim por 
diante, precisamos ter em mente essa relação com o indivíduo autônomo e pesar o custo de nossas novas escolhas institucionais para a autonomia individual.

26. Isso é, sem dúvida, mais agudo no que diz respeito ao tratamento das populações minoritárias, como tem demonstrado a história recente.

27. Hamilton, Madison e Jay, op. cit., p. 58-9.

28. É por isso que $O$ Federalista insiste na forma republicana, argumentando constantemente contra os excessos da democracia. Ao analisar o perigo das "facções", Madison definiu-as como "uma maioria ou uma minoria", e está claro que ele se preocupava mais com a primeira do que com a segunda. Para outra discussão, cf. meu ensaio "The Political Origins of Democracy", onde a primeira parte intitula-se "Politics after 'the' Revolution", e cuja preocupação é articular uma "política pós-revolucionária" por meio do desenvolvimento da relação entre a política republicana e a sociedade democrática. O ensaio encontra-se em Defining the Political, Londres: Macmillan Minneapolis: University of Minnesota Press, 1989, capítulo 15.

29. Lefort empresta o termo de Arquipélago Gulag de Soljenítsin, onde está aplicado aos residentes ainda ortodoxos dos campos, estendendo-o também àqueles intelectuais do Ocidente cuja obsessão por sistemas disciplinados para evitar zonas sombrias combina bem com um desejo moral de pensar bem de si próprios. Cf. Un homme en trop, Paris: Editions du Seuil, 1976, e The Marxian Legacy para o contexto interpretativo. Um aspecto um tanto diferente do mesmo fenômeno assume a forma de um deslize da recusa justificada de "culpar a vítima" por seu sofrimento em direção ao desejo injustificado (e, com freqüência, hipócrita e masoquista) de colocar-se a serviço da vítima, como se o sofrimento de alguma forma também desse à vítima o conhecimento para saber como escapar.

30. Essa afirmativa, baseada na experiência da Alemanha Oriental, não pode ser generalizada para toda a oposição do Leste Europeu. A "antipolítica" de Konrad pensava-se como uma moralidade de participação; o próprio nome da oposição polonesa, "Solidariedade", aponta na mesma direção. O objetivo, em ambos os casos, era a criação de uma sociedade civil autônoma. Entretanto, a dificuldade é a de que as duas estratégias foram concebidas dentro do modelo de estado totalitário (enfraquecido ou "Helsinquizado"). Não está claro como podem se desenvolver no novo contexto pós-totalitário. Outro aspecto do problema é o fato de a suposição de que há uma coletividade suprimida, que surgiria após o fim da repressão, fazer uso de uma imagem tomada do arsenal da teoria do marxismo.

31. Gorz, A. Und Jetzt Wohin? Berlin: Rotbuch, 1991. 